\title{
Bipolar Spectrum Disorders And Associated Factors Among Adults Attending An Antiretroviral Therapy Clinic In Gedeo Zone Health Centers, Southern Ethiopia [Corrigendum]
}

\author{
Belayneh Z, Alemu W, Mekuriaw B, Abebe Z. \\ Neuropsychiatr Dis Treat. 2019;15:503-509. \\ On review of the published manuscript the authors have \\ noticed several errors relating to the medication adherence \\ measurements.
}

The Morisky, Green and Levine scale (MGL) was actually used in the study, not the MMAS-4 as initially indicated. The use of the terms "Morisky medication adherence scale" and "Morisky 4-item medication adherence scale" on pages 504 and 505, respectively, need to be replaced with "the Morisky, Green and Levine Medication Adherence Scale".

Reference 49 on page 508 needs to be replaced with "Morisky DE, Green LW, Levine DM. Concurrent and predictive validity of a self-reported measure of medication adherence and long-term predictive validity of blood pressure control. Care. 1986;24(1):67-74."

The authors and the editor have confirmed these changes will have no impact on the conclusions of the study. The authors wish to apologize for this error.

\section{Publish your work in this journal}

Neuropsychiatric Disease and Treatment is an international, peerreviewed journal of clinical therapeutics and pharmacology focusing on concise rapid reporting of clinical or pre-clinical studies on a range of neuropsychiatric and neurological disorders. This journal is indexed on PubMed Central, the 'PsycINFO' database and CAS, and is the official journal of The International Neuropsychiatric Association (INA). The manuscript management system is completely online and includes a very quick and fair peer-review system, which is all easy to use. Visit http://www.dovepress.com/testimonials.php to read real quotes from published authors. 